\title{
KARAKTERISTIK SEORANG PELAYAN TUHAN BERDASARKAN 1 TIMOTIUS 3:1-7
}

Waharman

waharman@sttab.ac.id

\begin{abstract}
God's servant is a noble status, the glory is not based on his position, material and wages. But the glory is found in the characteristics of His servants. It is the characteristic that maintains one's service and maintains its status of service as noble. But many cases show the difficulty of a service to maintain its characteristics. In Paul's letter to Timothy reminded him to be able to assign a servant with high value criteria. Therefore through this writing, I will give the principles and characteristics of a minister based on 1 Timothy 3: 1-7.
\end{abstract}

Keywords: $\quad$ Characteristics, Servants of God.

Abstraksi: Pelayan Tuhan adalah status yang mulia, kemuliaan tersebut tidak didasarkan pada jabatannya, materinya dan upahnya. Tetapi kemuliaan tersebut didapatkan dalam karakteristik pelayan-Nya. Karakteristiklah yang mempertahankan pelayanan seseorang dan menjaga status sebagai pelayanannya tetap mulia. Namun banyak kasus menunjukkan sulitnya seorang pelayanan menjaga karakeristiknya. Dalam surat Paulus kepada Timotius mengingatkannya agar dapat menetapkan seorang pelayan dengan kriteria yang nilainya tinggi. Oleh karena itu melalui tulisan ini akan memberikan prinsip-prinsip dan karakteristik seorang pelayan berdasarkan 1 Timotius 3:1-7.

Kata Kunci: Karakteristik, Pelayan Tuhan.

\section{PENDAHULUAN}

Pelayan dalam Gereja Memiliki tugas dan tanggung jawab yang harus dikerjakan, secara garis besar seorang pelayan pastinya harus melakukan pelayanan, karena memang seorang pelayan harus melayani, Erastus Sabdono mengatakan bahwa, "pelayanan adalah kegiatan di sekitar Gereja yang dilakukan oleh mereka yang memiliki legitimasi (pengesahan) untuk pelayanan, yaitu para pejabat gereja dan yang lulus dari sekolah Alkitab."1 Karena memang pelayanan Kristen yang sejati selalu melibatkan Alkitab dan Roh Kudus. Alkitab memberikan berita dan misi yang utama bagi semua pelayan Kristen, dan bilamana Roh Kudus tidak aktif, maka pelayanan itu tidak akan menghasilkan buah rohani. $^{2}$ Pernyataan diatas menekankan bahwa memang dalam setiap diri pelayan Tuhan haruslah melibatkan Alkitab dan Roh Kudus dalam setiap pelayanannya, dan ini memang sangat betul, karena itulah yang harus dilakukan oleh setiap pelayan Tuhan. Trull dan Carter mengatakan bahwa :

\footnotetext{
${ }^{1}$ Erastus Sabdono, Pelayanan Yang Sesungguhnya (Jakarta : Rehobot Literature, 2017), 61

${ }^{2}$ Ronald W. Leigh, Melayani Dengan Efektif ( Jakarta : BPK Gunung Mulia, 2011), 3
} 
Dasar pelayanan Yang etis adalah pemahaman yang jelas tentang panggilan pelayanan. Jadi dapat ditarik kesimpulan bahwa seseorang menjadi pelayan harus mampu melakukan tugas dan tanggungjawabnya yaitu melakukan pelayanan dan memahami secara benar panggilan pelayanan itu. ${ }^{3}$

Karakteristik seorang pelayan Tuhan sebagai seorang pemimpin haruslah memiliki karakteristik yang benar, sebagai seorang pemimpin hal ini bisa diteladani dari kehidupan Yesus Kristus yang merupakan seorang pemimpin yang paling sempurna yang harus di teladani. Seorang pelayan Tuhan merupakan seorang pemimpin jemaat dan sebagai teladan yang harus di teladani oleh jemaat. ${ }^{4}$ Sehingga dalam hal ini sebagai pemimpin jemaat seorang pelayam Tuhan haruslah memiliki gambaran hidup atau karakteristik yang benar sebagai pemimpin bagi jemaat. Dalam hal ini menekankan bahwa seorang pelayan Tuhan haruslah meneladani kepemimpinan dari pada Tuhan Yesus ketika Tuhan Yesus menjadi pemimpin bagi para muridNya, dimana Yesus memilih gaya hidup sebagai seorang hamba yaitu untuk melayani. Sama seperti yang dikatakan Tuhan Yesus dalam Kitab Injil Markus "Karena Anak Manusia juga datang bukan untuk dilayani melainkan untuk melayani dan untuk memberikan nyawaNya menjadi tebusan bagi banyak orang."

Seorang pelayan Tuhan sebagai pemimpin bagi jemaat haruslah memiliki kepribadian yang diteladani dan membawa perubahan atau pengaruh positif kepada jemaat yang dilayani bukan membawa pengaruh negatif. Kepribadian atau karakteristik seorang pelayan Tuhan seperti inilah yang harus dimiliki sebagai pemimpin bagi jemaat yang ada di dalam gereja. ${ }^{6}$ Sehingga dapat dikatakan seorang pelayan Tuhan memiliki gaya hidup yang baik di mata jemaat yang sedang dilayani. Selanjutnya kepribadian dari setiap para

\footnotetext{
${ }^{3}$ Joe E. Trull Dan James E. Carter, Etika Pelayanan Gereja ( Jakarta : BPK Gunung Mulia, 2012),
} 18

${ }^{4}$ Frank mengatakan bahwa : Yesus adalam model pemimpin untuk diteladani oleh setiap orang yang ditetapkan. Yesus memilih gaya seorang hamba (Mat 20:20-28 ; Mark 10:35-44 ; Luk 22:24-27 ; Mark 9:35 ; Luk 9:48; Yoh 13:14). Orang yang ditetapkan sebagai hamba adalah satu perbedaan paling penting yang dapat dikembangkan oleh seorang pemimpin. Ia harus menekankan hubungan, tidak pernah dengan paksaan. Dia tidak pernah menuntut ketaatan ataupun ketundukan. Dia harus terus-menerus menunjukkan perhatian, kasih dan sikap sebagai hamba bagi semua yang bekerja dengannya. (Lih. : Frank Damazio, Memimpin Dengan Roh ( Yogyakarta : ANDI Offset, 2004), 123)

${ }^{5}$ Alkitab ( Kitab Injil Markus 10:45).

${ }^{6}$ Sopater dan Subandrijo mengatakan bahwa Seorang pemimpin ialah orang yang mampu untuk memimpin dan mampu membawa perubahan yang positif kepada orang yang sedang dipimpin. Kepemimpinan Gereja memiliki peran yang sangat penting dalam menumbuh kembangkan kehidupan bergereja umat Kristiani. Di dalam sistem ini setiap jemaat dikelola oleh Majelis yang berdiri atas PendetaPendeta, Penatua-Penatua dan para Diaken (Lih. : Sularso Sopater dan Bambang Subandrijo, Kepemimpinan dan Pembinaan Warga Gereja (Jakarta : Pustaka Sinar Harapan, 1998), 121) 
pelayan Tuhan tidak ada yang bermasalah karena adanya kerjasama yang baik satu dengan yang lainnya. ${ }^{7}$

Untuk melihat kepribadian dari pada setiap pelayan Tuhan harus melihat juga gaya kehidupan pelayan Tuhan itu, seperti yang dikatakan Trull Dan James: gaya hidup pelayan adalah unsur penting lain pelayanannya. Gaya hidup harus mengukuhkan, bukan menggoyahkan Injil yang ia beritakan. Gaya hidup seorang pelayan Tuhan di dalam Gereja akan menjadi kesaksian hidup untuk memperlihatkan kepada orang yang berada disekitar Gereja. Ketika pelayan Tuhan itu membawa berkat kepada orang yang disekitar Gereja akan memunculkan rasa ingin tahuan dari orang yang berada di sekitar Gereja atau masyarakat tentang kesaksian hidup kita. Jadi dalam hal ini perlu dipahami bahwa gaya hidup pelayan Tuhan sangat penting dalam pelayanan Gereja, karena dampak yang dimunculkan gaya hidup pelayan Tuhan bukan hanya kepada jemaat yang ada di Gereja akan tetapi kepada masyarakat yang ada di sekitar Gereja.

\section{METODOLOGI PENELITIAN}

Metode penelitian pada dasarnya merupakan cara ilmiah untuk mendapatkan data dengan tujuan dan kegunaan tertentu. ${ }^{8}$ Metodologi yang gunakan untuk memperdalam studi Theologia praktika tentang karakteristik seorang pelayan Tuhan adalah metodologi deskriptif dan penelitian lapangan. Dalam penelitian ini akan menggali theologia praktika yang dibangun oleh Rasul Paulus tentang karakteristik seorang pelayan Tuhan berdasarkan 1 Timotius 3:1-7. Metode analisis ini adalah suatu proses penelitian untuk menyelidiki suatu peristiwa dan untuk mengetahui keadaan yang sebenarnya serta memberikan gambaran sesuai dengan data yang ada. juga akan menganalisa dan membuat kajian eksegetikal untuk mencermati tulisan rasul Paulus khususnya seorang pelayan Tuhan berdasarkan 1 Timotius 3:1-7. Nazir menuliskan dalam bukunya mengenai pendapat whitney yang mengatakan metode deskriptif adalah pencarian fakta dengan interpretasi yang tepat. ${ }^{9}$

\section{Latar Belakang Teks 1 Timotius 3:1-7}

\footnotetext{
7 Abineno mengatakan : Pendeta-pendeta, penatua-penatua dan diaken-diaken sebagai pejabatpejabat Gereja ditugaskan untuk bekerja sama dalam jemaat. Oleh kerjasama itu mereka dapat saling membantu dan saling mengisi. Benar, bidang pelayanan mereka tidak sama: ada yang bertugas di bidang pemberitaan Firman, ada yang dibidang penggembalaan, ada yang di bidang diakoni, dan lain-lain. Tetapi pelayanan, mereka tidak dapat melakukan pelayanan mereka sendiri-sendiri, tanpa menghiraukan apa yang dikerjakan oleh pejabat-pejabat lain (Lih.: Joe E. Trull Dan James E. Carter, Etika Pelayanan Gereja ( Jakarta : Gunung Mulia, 2012), 87)

${ }^{8}$ Sugiyono, Metode Penelitian Manajemen (Yogyakarta : ALFABETA, cv, 2015), 24

${ }^{9}$ Moh Nazir, Metode Penelitian (Bogor : Ghalia Indonesia, 2014), 43
} 
Surat 1 Timotius ditulis oleh Rasul Paulus kepadaTimotius yang sedang menggembalakan jemaat yang ada di Efesus. Dalam surat ini Paulus menasehati Timotius yang sedang menggembalakan jemaat yang ada di Efesus, sehingga dengan hal itu Timotius dituntut menjadi seorang pemimpin yang memberikan teladan yang baik kepada jemaat yang ada di Efesus. Dalam pasal 1:1-3 menceritakan tentang kepemimpinan Kristen dalam memimpin jemaat, dimana dalam hal ini Timotius diberikan mandat untuk memilih pemimpin dalam jemaat seperti penatua/penilik jemaat, dan para penilik jemaat yang dipilih Timotius haruslah pemimpin memiliki karakteristik yang baik. Seperti yang dijelaskan oleh Drane dalam bukunya bahwa: Timotius harus juga yakin orang-orang yang diangkatnya untuk memegang jabatan pimpinan dalam jemaat-jemaat, mempunyai sifatsifat yang sama, dan merupakan jenis orang yang dapat dikagumi orang lain (1 Timotius $3: 1-13 ; 4: 6-16){ }^{10}$

Dari pandangan di atas menekankan bahwa setiap pemimpin jemaat haruslah memiliki kriteria atau syarat untuk menjadi seorang pemimpin jemaat dan dalam hal inilah Timotiusditekanklan bahwa pemimpin jemaat harus diyakinkan memenuhi syarat atau ketentuan sebagai pelayan Gereja yaitu memiliki karakteristik yang baik sebagai pelayan Tuhan yang dapat dikagumi oelh jemaat yang dilayani.

\section{KAJIAN EKSEGETIKAL 1 TIMOTIUS 3:1-7}

Dalam bagian ini akan mengeksegese kata-kata penting untuk mendapatkan kajian yang mendalam sehingga dapat mendalami dan memahami tentang karakteristik seorang pelayan Tuhan berdasarkan 1 Timotius 3:1-7, maka dalam hal ini akan mengkaji setiap poin-poin dalam ayat ini, untuk memperdalam kajian Eksegetikalnya. Karakteristik yang harus dimiliki oleh Pelayan Tuhan ialah:

\section{Karakteristik seorang Pelayan Tuhan dari Aspek Intergritas}

10 John Drane, Memahami Perjanjian Baru (Jakarta : Gunung Mulia, 2011), 396. Bdg. Stibbs: Jabatan penilik jemaat Allah, yang berarti mengepalai atau mengurus adalah tugas yang indah, yang harus betul-betul dilaksanakan. Jabatan itu menghendaki seorang lelaki yang tak bercacat, suci, dapat menahan diri dan murah hati, yang dapat mengendalikan keluarganya dengan baik. Janganlah yang baru bertobat, melainkan seorang yang tingkah lakunya sebagai Kristen selalu baik dan sudah diakui orang. Dia tidak memberi kesempatan kepada Iblis untuk menuduh dan memperdayakan dia, baik karena keangkuhannya sendiri, baik karena tuduhan-tuduhan mereka dari luar gereja. Begitu juga mereka yang melayani sebagai samas, seyogianya sudah terlebih dahulu membuktikan dirinya sendiri layak melalui perilaku Kristen yang mantap dan teliti, teristimewa mengenai soal-soal disiplin pribadi dan pengendalian keluarga. Sebab samas juga adalah pelayan, yang harus dilaksanakan dengan baik. Mereka yang melaksanakan dengan baik akan menjamin kedudukan mereka sebagai Kristen, dan biasanya menambah keyakinan terbuka dengan nama dapat menyebarkan iman Kristen. (A. M Stibbs, "1 Timotius" Dalam A. Lumbantobing (Et. Al), Tafsiran Alkitab Masa Kini-Jilid 3 (Jakarta : Yayasan Komunikasi Bina Kasih, 1996), 692). 
Karakteristik seorang pelayan Tuhan dapat dilihat dari intergritasnya, melayani Tuhan, untuk menjelaskan hal ini maka telah membuatnya dalam beberapat poin tentang karakteristik seorang pelayan dari aspek Integritas.

\section{Haruslah Seorang Tak Bercacat (Ayat 2)}

Frasa "haruslah seorang tak bercacat" diawali dengan kata "haruslah" yang memiliki arti dalam bahasa Yunani adalah $\delta \varepsilon ı$ (dei) dalam bentuk Verb subjunktif, ini menjelaskan kata kerja yang belum pasti akan tetapi pasti terjadi. Yang artinya suatu keharusan yang dimiliki oleh penilik jemaat yaitu seorang yang tak bercacat. frase seorang tak bercacat dalam bahasa Yunaninya yaitu ' $\nu \in \pi i \lambda \eta \pi \tau o \nu$ (nepilepton) kata dasar dari $\dot{\alpha} \nu \in \pi i \lambda \eta \mu \pi \tau o \varsigma$ (anepileptos) yang artinya sempurna dalam bentuk adjective accusative masculine singular no degree. ${ }^{11}$ Kasus ini menjelaskan kata sifat dan menunjuk kepada objek langsung, jadi dapat dipahami bahwa kata tak bercacat disini menunjuk kepada sifat yang harus dimiliki oleh penilik jemaat atau pelayan Tuhan. Kata $\dot{\alpha} \nu \epsilon \pi i ́ \lambda \eta \mu \pi \tau o \varsigma$ (anepileptos) dalam Greek Lexicon memakai kata not to be laid hold of; met. Irreprenhensible, unblamable, ${ }^{12}$ artinya tidak untuk ditanggungkan; tidak dapat diperbaiki, tidak dapat dicela, sedangkan dalam kamus Yunani-Indonesia kata $\alpha \nu \epsilon \pi i ́ \lambda \eta \mu \pi \tau o \varsigma$ memiliki arti tidak tercela dan tidak bercacat. ${ }^{13}$ Hal ini menjelaskan kepada kesempurnaan hidup yang harus dimiliki oleh penilik jemaat atau dapat dikatakan ini menekankan kepada prilaku penilik jemaat, bukan menunjuk kepada cacat secara fisik, akan tetapi ini menunjuk kepada cacat secara moral atau prilaku. Frasa seorang tak bercacat dijelaskan oleh Spiros dengan mengatakan, kata $\alpha \nu \epsilon \pi i ́ \lambda \eta \mu \pi \tau o \varsigma$ (anepileptos) diterjemahkan blameless $^{14}$ yang artinya suci, jadi sudah dapat dipahami bahwa tidak bercacat disini bukan menjelaskan cacat secara fisik akan tetapi ini menjelaskan cacat secara moral atau prilaku, dimana seorang pelayan Tuhan haruslah suci secara moral atau perilakunya.

Jadi memiliki pemahaman bahwa seorang tak bercacat ini, bukanlah merujuk kepada cacat secara jasmani, akan tetapi cacat disini berbicara tentang kehidupan atau kesaksian hidup yang penuh dengan kesucian atau tidak bercacat. "tidak bercacat" adalah kualifikasi kunci dari seluruh konteks untuk kepemimpinan didalam gereja. Frasa tersebut menyiratkan bahwa tidak ada cela untuk bisa dikritik. Karena memang menjadi seorang

\footnotetext{
${ }^{11}$ Bible Works, 19 Agustus 2019, 15:30

12 Harold K. Moulton, The Analytical Greek Lexicon Revised, (London : The Zondervan Corporation Grand Rapids, 1978), 28

${ }^{13}$ Barclay M. Newman, Kamus Yunani-Indonesia Perjanjian Baru, (Jakarta : Gunung Mulia, 2014), 12

14 Spiros Zodhiates, The Complete Word Study Dictionary New Testament, (America: AMG International, 1993), 170
} 
pemimpin jemaat itu haruslah menjadi teladan bagi jemaat itu sendiri sehingga seorang penilik haruslah sempurna dalam kehidupannya terutama dalam bidang attitude, dengan hal itu seorang penilik jemaat tidak dapat dicari cela untuk dikritik karena memang kehidupan attitudenya suci atau sempurna.

\section{Suami Dari Satu Istri (Ayat 2)}

Frasa "suami dari satu istri" dalam bahasa Yunaninya menggunakan kata $\mu \mathrm{L} \hat{\alpha} \varsigma$ $\gamma \cup \nu \alpha \iota k o ̀ \varsigma ~ ״ \alpha \nu \delta \rho$, (mias gunaikos andra) yang artinya laki-laki yang memiliki satu penolong, dalam bentuk noun genitive feminine singular common ${ }^{15}$ kata noun merupakan kata benda yang menunjuk kepada kepemilikan seorang penolong. Terjemahan secara

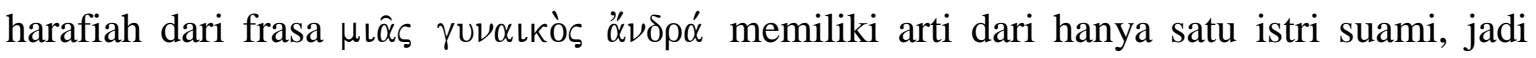
ketika dikalimatkan dapat ditulis suami dari hanya satu istri. ${ }^{16}$

Dari pemaparan di atas dsimpulkan bahwa suami dari satu istri ini menekankan seorang pelayan Tuhan haruslah orang yang menikahi satu istri ini menggambarkan kedewasaan mental serta menekankan kesetiaan yang dimiliki dalam diri setiap pelayan Tuhan, karena memang banyak para pelayan-pelayan sekarang memiliki masalah poligami atau memiliki istri simpanan. Oleh sebab itu rasul Paulus menekanlah bahwa seorang lakilaki haruslah memiliki satu istri.

\section{Dapat Menahan Diri (Ayat 2)}

Frasa "Dapat menahan diri” dalam bahasa Yunani menggunakan kata $\nu \eta \phi \alpha ́ \lambda\llcorner o \nu$ (nephalion) akar kata dari $\nu \eta \phi \alpha ́ \alpha \iota o \varsigma$ (nephalios) yang artinya tertata dan berpikir bersih dalam bentuk adjective normal accusative masculine singular no degree ${ }^{17}$ kata adjective disini menjelaskan kata sifat yang dimiliki secara normal oleh objek langsung yaitu pelayan Tuhan. Frasa "dapat menahan diri” menjelaskan kepada pemikiran yang dimiliki oleh pelayan Tuhan, bukan menjelaskan kepada tindakan akan tetapi menjelaskan pemikiran yang dimiliki oleh pelayan Tuhan haruslah normal, normal menunjukkan kepada ketidak cacatan atau gangguan atas pemikirannya. sedangkan kata " $\nu \eta \phi \alpha ́ \lambda\llcorner o \nu$ " (nephalion) dalam Greek Lexicon diterjemahkan to be sober, not intoxicated, to be vigilant, circumspect $^{18}$ artinya untuk sadar, tidak mabuk, untuk waspada, hati-hati. Sedangkan dalam buku kunci Yunani $\nu \eta \phi \alpha ́ \lambda \iota \nu \nu$ (nephalion) memiliki arti yang dapat

\footnotetext{
${ }^{15}$ Bible Works, 19 Agustus 2019, 16:00

${ }^{16}$ Hasan Susanto, Perjanjian Baru Interlinear Yunani-Indonesia dan Konkordansi Perjanjian Baru (PBIK) Jilid I..., 1112

${ }^{17}$ Bible Works, 21 Agustus 2019, 16:15

18 Harold K. Moulton, The Analytical Greek Lexicon Revised, (London : The Zondervan Corporation Grand Rapids, 1978), 277
} 
menahan diri, yang jiwanya/ pikirannya tenang. ${ }^{19}$ Frasa "dapat menahan diri” menjelaskan bagaimana pelayan Tuhan dengan siuman/sadar dalam melakukan pekerjaannya dan mengontrol dirinya dengan baik dalam pelayanannya.

\section{Bijaksana (Ayat 2)}

Kata bijaksana dalam bahasa Yunani menggunakan kata $\sigma \omega ́ \phi \rho o \nu \alpha ~(s o p h r o n a)$ dalam bentuk adjective normal accusative masculine singular no degree dari akar kata $\sigma \omega ́ \phi \rho \omega \nu$ (sophon) ${ }^{20}$ yang artinya bijaksana, hati-hati, menjaga diri, sederhana, murni ${ }^{21}$ kata bijaksana merupakan kata sifat yang berbentuk normal dan ini menunjuk kepada objek langsung yaitu penilik jemaat, jadi dapat dipahami kata bijaksana ini menekankan penilik jemaat haruslah orang yang hati-hati, menjaga diri dan sederhana. Rasul Paulus memberi pemahaman bahwa kata ini adalah karakter yang harus dimiliki oleh penilik jemaat. Balz juga menekankan bahwa pengertian dari kata $\sigma \omega ́ \phi \rho \omega \nu$ (sophron) : soudness of mind, selfcontrol and moderation, reasonableness, decency. ${ }^{22}$ Artinya ialah kesehatan pikiran, pengendalian diri dan pengereman, bebijaksanaan, kesopanan. Dari pernyataan di atas menyimpulkan bahwa kata bijaksana disini bukan hanya berbicara mengenai bijak dalam mengambil keputusan tetapi bijak disini juga menekankan kepada penguasaan diri. Seperti dalam pelayanan sering gembala atau pelayan terseret dengan persoalan yag ada dan mereka tidak dapat menguasai diri mereka, oleh sebab itu rasul Paulus menekankan seorang pelayan Tuhan haruslah dapat menguasai diri.

\section{Sopan (Ayat 2)}

Kata sopan dalam bahasa Yunani menggunakan kata кó $\mu \iota \circ \nu$ (Kosmion) dalam

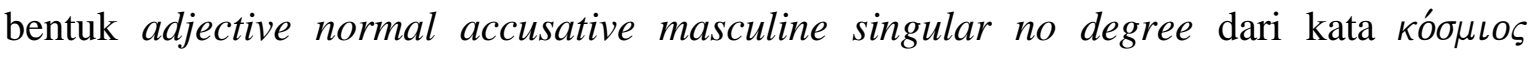
(kosmios) adjective merupakan kata sifat yang menunjuk kepada objek langsung yaitu penilik jemaat, sehingga dapat dipahami kata sopan merupakan kata sifat yang harus dimiliki oleh pelayan Tuhan, kata sopan menunjuk kepada kata terhormat, ini menjelaskan penilik jemaat haruslah orang yang terhormat atau dapat dikatakan orang yang disegani dalam perilakunya atau yang memiliki wibawa sebagai seorang pemimpin, baik dalam perkataan ataupun dalam tindakan dan tutur kata, pelayan Tuhan haruslah menggunakan kata-kata yang sopan dan ini yang membuat dia menjadi orang terhormat.

\footnotetext{
19 B. F. Drewes, Kunci Bahasa Yunani Perjanjian Baru Surat Roma Hingga Wahyu, (Jakarta : Gunung Mulia, 2010), 216

${ }^{20}$ Bible Works, 23 Agustus 2019, 09:30

21 Barclay M. Newman, Kamus Bahasa Yunani-Indonesia Untuk Perjanjian Baru ( Jakarta : Gunung Mulia, 2015) 168

${ }^{22}$ Horst Balz dan Gerhard Schneider, Exegetical Dictionary Of The New Testament Volume 3, (Germany : Kohlhammer GmbH, Stuttgart, 1993), 329
} 
Pernyataan diatas memahami bahwa kata sopan ini mengacu bukan hanya kepada penampilan akan tetapi terhadap pemikiran yang jorok dan juga kesopanan dalam perkataan, hal inilah yang harus dimiliki oleh seorang pelayan Tuhan, ia haruslah orang yang tertib dan memiliki wibawa dari penampilannya.

\section{Karakteristik Seorang Pelayan Tuhan dari Aspek Sosial}

Karakteristik seorang pelayan Tuhan dapat juga dilihat dari hubungan sosialnya sebagai seorang pelayan, untuk menjelaskan hal ini, maka telah membuatnya dalam beberapa poin tentang karakteristik seorang pelayan Tuhan dari aspek sosial.

\section{Suka Memberi Tumpangan (Ayat 2)}

Frasa "Suka memberi tumpangan" dalam bahasa Yunani menggunakan kata $\varphi \imath \lambda o \xi \varepsilon v o \varsigma$ (philoxenos) yang artinya yang suka memberi tumpangan ${ }^{23}$ frasa ini memiliki bentuk Adjective masculine singular accusative no degree, adjective disini menjelaskan kata sifat yang menunjuk kepada objek langsung yaitu penilik jemaat, dengan hal itu dapat dipahami suka memberi tumpangan merupakan sifat yang harus dimiliki oleh penilik jemaat dan ini merupakan kebiasaan yang dilakukan oleh pelayan Tuhan yaitu suka memberi tumpangan terlebih kepada orang yang baru dijumpai. berbicara mengenai kata $\varphi \imath \lambda_{0} \xi \varepsilon v o \varsigma$, (philogenos) Balz mendefenisikan dengan terjemahan "in the list of qualifications for bishop; be hospitable to one another without grumbling, ${ }^{24}$ yang artinya dalam daftar kualifikasi hamba Tuhan; jadilah ramah untuk satu sama lain tanpa menggerutu.

Jadi dapat dimengerti bahwa kata suka memberi tumpangan memiliki pengertian yang cukup dalam, bahwa disini dijelaskan suka memberi tumpangan merupakan sifat yang harus dimiliki oleh pelayan Tuhan dan dalam hal ini pelayan Tuhan ditekankan bahwa dia adalah teman dari pada jemaat yang dilayani, dan oleh karena itu pelayan harus menunjukkan sifat yang harus dimiliki ialah seorang teman yang penuh kasih, dan ramah tamah. Dengan hal ini menjelaskan seorang pelayan Tuhan haruslah menjadi teman bagi jemaat dan menunjukkan rasa kasihnya kepada jemaat yang dilayani dan kepada orang yang baru dikenal, kasih disini adalah kasih yang tidak melihat hubungan keluarga atau kasih yang tidak terbatas.

\section{Cakap Mengajar Orang (Ayat 2)}

\footnotetext{
${ }^{23}$ Hasan Susanto, Perjanjian Baru Inteliniear Yunani-Indonesia jilid I dan Konkordansi PB (PBIK) Volume II..., 795

${ }^{24}$ Horst Balz dan Gerhard Schneider, Exegetical Dictionary Of The New Testament Volume 3, (Germany : Kohlhammer GmbH, Stuttgart, 1993), 427
} 
Frasa "cakap mengajar orang" dalam bahasa Yunani menggunakan kata $\delta 1 \delta \alpha \kappa \tau \iota \kappa o \varsigma$ (didaktikos,) dalam bentuk Adjective Masculine singular Accusative no degree yang artinya yang pandai mengajar. ${ }^{25}$ Frasa ini menjelaskan kata sifat dan menunjuk kepada kekuatan yang dimiliki oleh objek itu sendiri yaitu penilik jemaat. sehingga dapat dipahami bahwa cakap mengajar orang merupakan kata sifat yang harus dimiliki oleh penilik jemaat dan ini menekankan kekuatan dari pada penilik itu sendiri. Sehingga frasa cakap mengajar orang menekankan kepada keahlian seorang pelayan Tuhan dalam mengajar. Sedangkan Harold menegaskan bahwa kata $\delta ı \delta \alpha \tau \imath \kappa o \varsigma ~(d i d a k t i k o s)$ diterjemahkan or qualified to teach. ${ }^{26}$ Artinya ialah berkwalitas untuk mengajar. Sehingga dapat dimengerti cakap mengajar orang memberikan penjelasan mengenai kemampuan yang dimiliki oleh Pelayan Tuhan dalam mengajarkan kebenaran kepada jemaat yang dilayani dan perlu diketahui cakap mengajar orang bukan hanya berbicara kepada keahlian pelayan Tuhan mengajar akan tetapi ini juga berbicara kualitas atau memiliki mutu dalam menguasai firman Tuhan.

Seorang penilik jemaat harus memiliki kualitas yang baik dalam mengajar maupun dalam menguasai Firman Tuhan. Serta membawa perubahan kepada jemaat yang dilayani. Dengan kata lain ketika pelayan Tuhan memberikan pengajaran atau berkhotbah jemaat dengan mudah mengerti apa yang ia sampaikan, sehingga dengan itu jemaat memiliki perubahan dalam hidupnya karena mereka mengerti makna pengajaran yang disampaikan oleh pelayan Tuhan kepada mereka sebagai pendengar dari pada pengajaran pelayan Tuhan.

\section{Bukan Peminum (Ayat 3)}

Kata Bukan peminum dalam bahasa Yunani menggunakan kata $\mu \eta \pi$ $\pi$ oovvo (paroinos) yang artinya yang suka mabuk ${ }^{27}$ kata $\mu \eta$ sendiri memiliki kasus particle negative artinya dari particle negative ialah memiliki unsur negative sedangkan kata $\pi \alpha \rho o ı v o \zeta$ memiliki kasus naun masculine singular accusative, kata naun memiliki artinya kata benda yang bersifat menguasai objek itu sendiri, jadi dapat dimengerti bahwa bukan pemabuk, menjelaskan bukanlah orang yang suka dengan mabuk-mabukan. Sehingga dengan hal itu rasul Paulus memberikan nasehat bahwa penilik jemaat bukanlah peminum

\footnotetext{
${ }^{25}$ Hasan Susanto, Perjanjian Baru Intelinear Yunani-Indonesia dan Konkordansi PB (PBIK) Volume II..., 203

26 Harold K. Maulton, The Analytical Greek Lexicon Revised, (London : The Zondervan Corporation, 1078), 98

${ }^{27}$ Hasan Susanto, Perjanjian Baru Interlinear Yunani-Indonesia dan Konkordansi PB (PBIK) Volume II..., 615
} 
atau orang yang suka mabuk-mabukan. kata mabuk sendiri memiliki terjemahan dalam bahasa Inggris yaitu Drinking (Mabuk), berbicara hal ini Alister mengatakan dalam buku The NIV Thematic bahwa: cripture lays down no general prohibition of the consumption of alcohol, but warns against its abuse. ${ }^{28}$

Dengan pernyataan-pernyataan di atas menyimpulkan frasa "bukan peminum" disini menekankan penyalahgunaan daripada minuman anggur, sekarang ini banyak orang yang meminum anggur dengan maksud memuaskan hasrat dalam dirinya dan menyalahgunakan fungsi daripada minuman. Sehingga dalam ayat ini rasul Paulus menekankan seorang pelayan Tuhan janganlah orang yang diperbudak oleh minuman keras.

\section{Bukan Pemarah (Ayat 3)}

Kata bukan pemarah dalam bahasa Yunani menggunakan kata $\pi \lambda \eta \kappa \tau \eta \varsigma$ (plektes) dengan kasus Naun Masculine Singular accusative kata naun merupakan kata benda yang bersifat menguasai objek langsung itu sendiri, sehingga dengan hal itu dapat dipahami pemarah disini memiliki arti orang yang suka berkelahi ${ }^{29}$ sedangkan Balz dan Schneider menjelaskan kata $\pi \lambda \eta \kappa \tau \eta \varsigma$ (plesktes) diterjemahkan not be a Quarrelsome man. ${ }^{30}$ Artinya ialah laki-laki yang suka cekcok, dalam KBBI Cekcok memiliki arti berbantah dan berselisi. ${ }^{31}$ Dengan pembahasan yang sama Spiros juga menjelaskan bahwa kata $\pi \lambda \eta \kappa \tau \eta \varsigma$ (plesktes) memiliki arti a strike, a violent person, figuratively a revile, one who by reproachful and upbraiding language wounds the conscience of his brethren, a contentious person, a quarreler (suatu serangan, seorang orang kejam, yang secara kiasan suatu mencaci, orang yang oleh penuh celaan dan mencela luka bahasa suara hati dari saudaranya, seorang orang suka bertengkar, suatu bertengkar) pernyataan ini menjelaskan bahwa kata pemarah memiliki arti yang cukup mendalam dimana pemarah dapat diartikan seorang yang kejam atau dengan kata lain otoriter, suka mencaci maki, orang yang penuh dengan celaan atau kesalahan, jadi dengan hal itu seorang pelayan Tuhan janganlah seorang yang sangat kejam atau suka mencaci orang-orang yang dilayani atau bertindak dengan kepemimpinan yang otoriter terhadap jemaat yang dilayani.

\footnotetext{
${ }^{28}$ Alister E. McGrath, The NIV Thematic Study Bible..., 1457

${ }^{29}$ Hasaan Susanto, Perjanjian Baru Interlinear Yunani-Indonesia dan Konkordansi PB (PBIK) Volume II..., 647

${ }^{30}$ Horst Balz Dan Gerhard Schneider, Exegetical Distionary Of The New Testament volume 3, (Germany : Kohlhammer GmbH, Stuttgart, 1993), 106

${ }^{31}$ Siswo Prayitno Hadi Podo, Kamus Besar Bahasa Indonesia, (Jakarta : Pustaka Phoenix, 2007), 155
} 
Jadi seorang penilik jemaat bukanlah orang yang langsung main tangan ketika jemaat yang dilayani melakukan pelanggaran, atau tidak memukul ketika melihat kesalahan jemaat yang dipimpin, akan tetapi seorang penilik jemaat mengikuti teladan Tuhan Yesus yang tidak pernah mebalas cacian dengan cacian, karena memang seorang penilik jemaat haruslah orang yang mampu membawa jemaat kepada perubahan yang lebih baik ketika jemaat melakukan kesalahan. Dengan hal itu menyimpulkan kata bukan pemarah disini, hanya menggambarkan mimic wajah yang tidak suka akan tetapi marah disini memiliki pengertian orang yang suka melakukan kekerasan atau adu fisik. Sehingga dengan hal itu rasul Paulus menekankan supaya seorang pelayan Tuhan janganlah orang yang suka berantam dengan adu fisik.

\section{Bukan Hamba Uang (Ayat 3)}

Bukan hamba uang dalam bahasa Yunani menggunakan kata $\alpha \varphi \imath \lambda$ - $\alpha \rho \gamma \nu \rho \circ \varsigma$ (aphilarguros) dalam bentuk adjective masculine singular accusative no degree yang artinya yang tidak suka uang ${ }^{32}$ kata sifat ini menunjukkan kepada objek langsung itu sendiri yaitu pelayan Tuhan dan memiliki unsur negative yang akan ditimbulkan dari sifat itu sendiri ketika dihidupi yaitu tidak menyukai uang. sedangkan Balz menjelaskan dalam

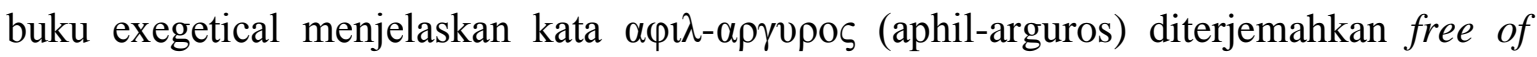
avarince, not covetous. ${ }^{33}$ Artinya ialah bebas dari ketamakan atau tidak tamak jadi seorang pelayan Tuhan haruslah orang yang bebas dari ketamakan.

Oleh sebab itu seorang penilik jemaat janganlah orang yang tamak, dan ini cenderung kepada keuangan, sehingga dalam memimpin jemaat seorang penilik tidak mementingkan dirinya sendiri dan mencari keuntungan dari pelayanan kepada Tuhan. Dan Welt juga menekankan bahwa bukan hamba uang dapat dipahami of course this refers to loving what money can do. it is this quality of heart that makes a man covetous. the idolatry of money-worship is ever near us. ${ }^{34}$ memahami bahwa seorang penilik jemaat yang mengasihi uang, itu merupakan bukti dari pada kualitas hatinya, karena ketika seorang pelayan Tuhan sudah suka dengan uang atau tamak akan uang, dapat dipastikan motivasinya melayani juga ingin mencari uang, itu membuktikan bahwa kualitas hatinya dihadapan Tuhan sangatlah rendah karena mau diperbudak oleh uang sehinga dengan hal itu rasul Paulus menasehatkan pelayan Tuhan janganlah orang yang cinta akan uang. Jadi

\footnotetext{
${ }^{32}$ Hasan Susanto, Perjanjian Baru Interlinear Yunani-Indonesia dan Konkordansi PB (PBIK) Volume II..., 136

${ }^{33}$ Horst Balz dan Gerhard Schneider, Exegetical Dictionary Of The New Testament volume 1, (Germany : Kohlhammer GmbH, Stuttgart, 1993), 183

${ }^{34}$ Don De Welt, Paul's Letters To Timothy And Titus, (Yerusalem : College Press, 1961), 62
} 
dapat disimpulkan bahwa bukan hamba uang ialah menekankan pelayan Tuhan janganlah orang yang tamak akan uang atau tidak puas dengan apa yang dimiliki dan selalu ingin menguasai dengan penih hasrat. Sehingga rasul Paulus menekankan hal itu, karena memang banyak sekarang ini pelayan Tuhan jatuh karena uang dan menjual imannya karena uang.

\section{Seorang Kepala Keluarga Yang Baik (Ayat 4)}

Frasa "Seorang kepala keluarga yang baik" dalam bahasa Yunani menggunakan kata tô̂ (tou) article masculine singular genitive ini menjelaskan suatu artikel yang bersifat menguasai objek tidak langsung ioíou (idiou) ini memiliki kasus adjective masculine singular genitive no degree ini menjelaskan kata sifat yang menguasai objek tidak langsung tersebut oľkou (oikou) ini memiliki kasus naun masculine singular genitive kasus ini menjelaskan kata benda yang harus dimiliki oleh objek tidak langsung itu sendiri $\kappa \alpha \lambda \omega \varsigma$ (kalos) ini memiliki kasus adverb no degree kasus ini menekankan unsur yang bersifat tidak ada $\pi \rho 0 \ddot{\sigma} \sigma \alpha \dot{\alpha} \mu \in \nu \mathrm{o \nu}$, (proistamenon) verb present masculine passive middle singular acusative kasus ini menjelaskan kata kerja yang sedang dilakukan dan ini menejelaskan kepasifan yang dimiliki oleh objek itu sendiri, dengan hal itu dapat dipahami pelayan Tuhan sebagai kepala keluarga yang baik ialah kepala keluarga yang dapat diteladani oleh anak-anaknya, dan ini dibuktikan oleh pelayan Tuhan dalam kehidupannya sehari-hari. $^{35}$

Jadi frasa seorang kepala keluarga yang baik memberikan penjelasan, seorang pelayan Tuhan yang diakui oleh anak-anaknya dalam memimpin rumahtangganya, dan ia juga menjadi kebanggaan anak-anaknya dan menjadi teladan bagi keluarganya baik dari karakternya sebagai seorang kepala keluarga. Dengan hal itu menyimpulkan seorang pelayan Tuhan menjadi kepala keluarga yang baik, ini menekankan kepada keberhasilan seorang pelayan Tuhan dalam memimpin keluarganya. Karena banyak pelayan Tuhan sekarang ini, dalam pelayanan ia cukup berhasil akan tetapi dalam rumahtangganya ia gagal dan tidak mampu menciptakan keharmonisan dalam rumah tangganya.

\section{Kepala Keluarga yang Disegani (Ayat 4)}

Seorang penilik jemaat juga haruslah kepala keluarga yang disegani, kata disegani disini dari kata dasar segan, kata segan dalam Kamus Besar Bahasa Indonesia (KBBI) ialah tidak sudi, tidak mau, tidak suka, malas berbuat sesuatu; enggan; merasa malu takut,

\footnotetext{
${ }^{35}$ Hasan Susanto, Perjanjian Baru Interlinear Yunani-Indonesia Dan Konkordansi Perjanjian Baru Jilid I..., 1113
} 
hormat. ${ }^{36}$ Dalam bahasa Yunani kata disegani memakai kata $\pi \rho \circ \iota \sigma \theta \eta \mu \iota$ (proistemi) dalam bentuk verb participle present middle acusative masculine singular. ${ }^{37}$ Frase seorang kepala keluarga yang dihormati diterjemahkan yaitu anak-anaknya haruslah patuh tanpa menggerutu, dari versi ini menekankan bahwa seorang kepala keluarga yang dihormati ini merujuk kepada kepatuhan anak-anaknya kepada penilik jemaat tanpa menunjukkan rasa ketidaksenangan ketika penilik jemaat memberikan perintah kepada anak-anaknya.

Jadi dapat disimpulkan seorang kepala keluarga yang disegani ialah menekankan kepada sikap segan yang dilakukan oleh anak pelayan kepada pelayan sebagai kepala keluarga, karena memang banyak terjadi dalam pelayanan, anak-anak tidak mau mendengarkan perkataan orang tuannya lagi dan malah mereka tidak menunjukkan rasa sopan dan segan kepada orang tuanya karena memang orangtuannya menunjukkan sikap tidaak terhormat dihadapan anak-anaknya. Sehingga dengan hal itu rasul Paulus menasehatkan seorang pelayan Tuhan haruslah seorang kepala keluarga yang disegani oleh anak-anaknya, ini menunjukkan kemampuan seorang pelaayan Tuhan sebagai kepala keluarga dalam membentuk karakter anak-anaknya.

\section{Seorang Kepala Keluarga Yang Dihormati (Ayat 4)}

Seorang pelayan Tuhan haruslah seorang kepala keluarga yang dihormati, kata

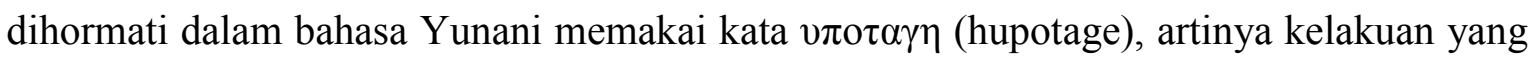
terhormat, kesungguhan, dalam bentuk naun feminim singular genitive, kata naun disini menjelaskan kata benda yang bersifat menolong dan ini menunjuk kepada objek tidak langsung. Jadi dapat dipahami kata dihormati merupakan tindakan atau perilaku yang ditunjukkan pelayan Tuhan sebagai seorang kepala keluarga ialah kelakuan yang terhormat, sehingga dengan hal itu anak-anaknya akan memiliki rasa hormat terhadapnya

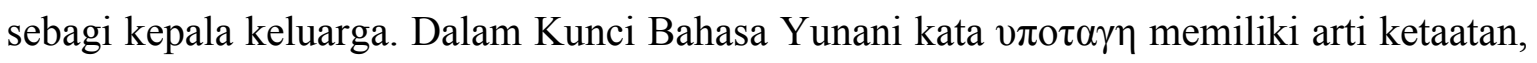
ketaklukan; ${ }^{38}$ jadi dapat dipahami bahwa seorang pelayan Tuhan haruslah kepala keluarga yang dapat membuat ia ditaati atau dia dapat menaklukan keluarganya dibawah pimpinannya. Jadi dapat disimpulkan kata dihormati memberikan penekanan, tindakan yang dilakukan oleh anak-anak penilik jemaat kepadanya sebagai kepala keluarga, karena penilik jemaat menunjukkan karakter yang sangat terhormat dan itu menjadi teladan bagi anak-anaknya.

\section{Memiliki Nama Baik Di Luar Jemaat (Ayat 7)}

\footnotetext{
${ }^{36}$ Siswo Prayitno Hadi Podo, Kamus Besar Bahasa Indonesia Edisi Baru, (Jakarta : Media Pustaka Phoenix, 2007) 762

${ }^{37}$ Bible Works, 25 Agustus 10:00

${ }^{38}$ Drewes, Kunci Bahasa Yunani Perjanjian Baru, (Jakarta : Gunung Mulia, 2011), 216
} 
Karakteristik seorang pelayaan Tuhan yang baik dapat diketahui ialah ketika ia memiliki nama baik dilingkungan masyarakat, frase "memiliki nama baik diluar jemaat" dalam bahasa Yunani memakai kata, $\delta \varepsilon 1$ (dei) artinya harus, ini memiliki kasus verb orang ke-3 singular present aoris indicative kasus ini menjelaskan kata kerja orang ketiga tunggal, dan sedang dilakukandan hanya sekali dilakukan oleh pelayan itu sendiri. $\delta \varepsilon(\mathrm{de})$ artinya lalu, ini memiliki kasus conjunction coordinating continuative ini menjelaskan kata penghubung yang mengkordinir tindakan objek itu sendiri אal (kai) artinya juga, ini memiliki kasus adverb no degree ini merupakan kata sifat $\mu \alpha \rho \tau v \rho ı v$ (marturian) artinya reputasi, ini memiliki kasus naun feminime singular accusative kasus ini menjelaskan kata benda yang bersifat menolong pelayan Tuhan $\kappa \alpha \lambda \eta \nu$ (kalen) artinya baik, ini memiliki kasus adjective feminime singular accusative no degree kasus ini menjelaskan kata sifat, kasus feminim $\varepsilon \chi \varepsilon ı v$ (exein) artinya mempunyai, ini memiliki kasus verb present accusative infiniteve kasus ini menjelaskan kata kerja yang sedang dilakukan oleh objek itu sendiri aлo (apo) artinya terhadap, ini memiliki kasus preposition genitive ini menjelaskan kata depan dari pada objek itu $\tau \omega v$ (ton) artinya orang-orang, ini memiliki kasus article masculine plural genitive kasus ini menjelaskan suatu artikel $\varepsilon \xi \omega \theta \varepsilon v$ (egoten) artinya luar, ini memiliki kasus adverb no degree ini menjelaaskan kata keterangan jadi secara harafiah diartikan harus lalu juga reputasi baik mempunyai terhadap orang-orang luar. $^{39}$

Jadi seorang penilik jemaat, sebagai pelayan Tuhan haruslah memiliki nama baik atau dengan kata lain ia adalah orang yang disukai dilingkungan sekitarnya, terkhususnya bagi mereka yang belum percaya kepada Yesus Kristus, dan ini juga menjelaskan seorang penilik jemaat menjadi saksi Kristus kepada orang-orang yang belum percaya melalui gaya hidup yang ia tunjukkan. menyimpulkan soerang pelayan Tuhan yang memiliki nama baik diluar, ini menekankan kehidupan pelayan itu yang sangat menarik bagi orang disekitarnya dan ia sangat dikagumi oleh masyarakat yang disekitarnya. Karena memang banyak pelayan sekarang dibenci oleh orang-orang disekitarnya, kemungkinan itu dikarenakan pembawaan pelayan itu tidak baik dan karakternya tidak membawa berkat bagi orangorang disekitarnya. Sehingga dengan hal itu rasul Paulus menasehatkan seorang pelayan haruslah orang yang memiliki nama baik di lingkuan masyarakat.

\section{Karakteristik Pelayan Tuhan Dari Aspek Rohani}

\footnotetext{
${ }^{39}$ Hasan Susanto, Interlinear jilid I..., 1113
} 
Karakteristik seorang pelayan Tuhan dapat dilihat dari aspek rohaninya, untuk menjelaskan hal ini, maka telah membuatnya dalam beberapapoin tentang karakteristik seorang pelayan Tuhan dari aspek rohani.

\section{Seorang Pelayan Tuhan Yang Telah Lahir Baru (Ayat 6)}

Seorang pelayan Tuhan yang memiliki karakteristik yang baik ialah ia haruslah seorang yang sudah lahir baru atau sudah lama menjadi orang Percaya, hal ini merujuk kepada kepribadian yang sudah beres atau sudah lahir baru duluan ini bersifat sudah lampau bukan sedang terjadi, karena memang orang yang baru lahir baru cenderung menyombongkan diri saat pelayanan, frase janganlah ia seorang yang baru lahir baru Dalam bahasa Yunani diawali dengan kata janganlah, kata janganlah memakai kata $\mu \eta$ ini memiliki kasus particle negative artinya yang memiliki unsur negative sedangkan kata

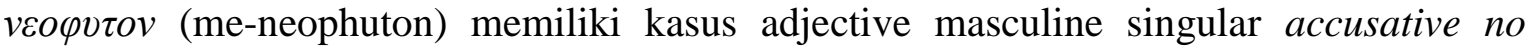
degree, ini menjelaskan kata sifat yang bersifat memerintah objek langsung itu sendiri yaitu pelayan Tuhan, dengan hal ini dapat diartikan frasa janganlah ia seorang yang barus bertobat ini menjelaskan jangan yang baru ditanam. ${ }^{40}$

Jadi dapat disimpulkan janganlah seorang yang baru bertobat ini memberikan penekanan, seorang penilik jemaat tidak sombong saat dijadikan menjadi pemimpin jemaat, karena memang seorang yang baru bertobat perlu banyak yang harus dipersiapkan baik itu secaraa rohani maupun mental. Seperti tanaman yang baru ditanam belum jelas pertumbuhannya, apakah dia akan mati atau tetap hidup nantinya, begitu juga seorang yang baru bertobat, kepribadiannya masih belum jelas apalagi berbicara mengenai kerohanian, sangat masih belum jelas, sehingga dengan terpilihnya dia menjadi pemimpin jemaat dia akan memimpin dengan kesombongan dalam melayani dan ini dilakukan untuk menutupi karohaniannya yang masih abu-abu, sehingga dengan hal itu rasul Paulus menekankan seorang pelayan janganlah yang baru bertobat, karena resikonya cukup besar ketika dia dijadikan pemimpin bagi jemaat.

\section{APLIKASI}

Dalam bagian ini akan memberikan aplikasi karakteristik seorang pelayan Tuhan berdasarkaan 1 Timotius 3:1-7. Karakteristik seorang pelayan Tuhan merupakan hal yang sangat penting untuk dimiliki dan ditunjukkan oleh para pelayan Tuhan.

${ }^{40}$ Hasan Susanto, Perjanjian Baru Interlinear Yunani-Indonesia dan Konkordansi PB (PBIK) Volume II...,534 


\section{Seorang Pelayan Tuhan Haruslah Memiliki Integritas}

Dalam kepemimpinan sebagai seorang pelayan Tuhan, haruslah ia memiliki integritas sebagai pelayan itu sendiri. kita tahu integritas berbicara mengenai tindakan yang sesuai dengan ucapan yang dilakukan atau dengan kata lain bukti nyata dari apa yang ia ucapkan itulah merupakan integritas, jadi dalam hal ini seorang pelayan Tuhan haruslah berintegritas, ini dapat dilihat dari kehidupannya yaitu ia haruslah orang yang tak bercacat, atau kehidupannya haruslah suci sebagai pelayan Tuhan dan ini haruslah ia tunjukkan dalam kehidupanya sehari-hari sebagai seorang pelayan Tuhan, ia juga harus memiliki satu istri saja, tidak ada poligami dan ini yang harus dipegangnya sebagai seorang pelaya Tuhan, karena dalam kekristenan sebuah keluarga haruslah dibangun di dalam Kristus Yesus, dan bertujuan untuk memuliakan Tuhan, sehingga dengan hal itu tidak akan ada namanya poligami dalam keluarga, sama seperti yang dikatakan oleh Bagus “ Keluarga Kristen tidak akan terjadi dengan sendirinya, tapi perlu curahan energi terbaik untuk membangunya dalam anugerah Tuhan. karena keluarga didesain dan diciptakan oleh Allah sendiri, maka tujuan keluarga adalah untuk memuliakan Allah di dalam Kristus Yesus". 41 disini juga seorang pelayan Tuhan haruslah orang yang dapat menyelesaikan masalah, bijak dalam mengambil keputusan untuk setiap perencanaan dalam pelayanan, dan seorang pelayan Tuhan haruslah orang yang sopan dalam bertutur kata dan cara berpakaian yang berwibawah saat melayani Tuhan. hal inilah yang harus ditunjukkan seorang pelayan Tuhan yang memiliki integritas sebagai pelayan.

\section{Seorang Pelayan Tuhan Haruslah Memiliki Hubungan Sosial}

Seorang pelayan Tuhan yang baik harus juga memiliki hubungan sosial yang baik, hubungan sosial merupakan sosialisasi yang dibangun oleh pelayan baik itu kepada jemaat yang dilayani, baik kepada keluarga serta kepada orang lain yang ada disekitar pelayanan itu. seorang pelayan Tuhan yang memiliki hubungan sosial yang baik berarti pembawaan pelayan yang dapat diterima oleh siapa saja yang ada disekitarnya, bukan membawa keributan, itulah seorang pelayan Tuhan yang memiliki hubungan sosial yang baik, seorang pelayan Tuhan juga dapat menjadi teladan bagi keluarganya sendiri terkhusus kepada anak-anaknya, karena pelayan Tuhan merupakan pemimpin bagi anak-anaknya sehinggga ia harus menjadi teladan bagi keluarganya. sehingga dengan hal itu seorang pemimpin memberi perhatian pada ajaran dan panggilan keteladanan, dengan hal itu ia 2001), 2

\footnotetext{
${ }^{41}$ Bagus Surjantoro, Membangun Keluarga Untuk KemuliaanNya (Jakarta : Obor Mitra Indonesia,
} 
mampu menjadi teladan yang baik bagi orang-orang disekitarnya. maka, dari sana akan lahirlah pengaruh, wibawa dan kekuatan yang besar. ${ }^{42}$ Terkhusus untuk anak-anaknya, sehingga dengan hal itu terbangun karakter yang baik bagi anak-anaknya itu dikarenakan pengaruh dari keteladanan yang diberikan oleh pelayan Tuhan sebagai pemimpin rumah tangga. Seorang pelayan Tuhan juga haruslah memiliki reputasi yang baik dilingkungan sekitarnya, dengan kata lain pembawaan pelayan Tuhan dapat diterima dengan baik oleh orang-orang yang disekitarnya.

\section{Seorang Pelayan Tuhan Haruslah Orang Yang Telah Lahir Baru}

Seorang Pelayan Tuhan juga haruslah orang yang telah lahir baru terlebih dahulu, karena memang menjadi seorang pelayan Tuhan haruslah dapat membawa pengaruh kerohanian yang baik kepada orang yang dilayaninya, oleh sebab itulah pelayan Tuhan dituntut haruslah orang yang telah lahir baru. ini bertujuan supaya kerohanian dari pada setiap pelayan Tuhan tidak dapat diragukan lagi, baik itu secara mental dan dari segi iman percaya mereka. sehingga dengan hal ini pelayan Tuhan dapat membawa pengaruh yang baik kepada jemaat yang dilayaninya. untuk mencapai hal ini pelayan Tuhan haruslah membangun kerohanian mereka sehingga mereka dapat menjadi teladan bagi orang yang dilayani dan membawa pengaruh. membangun kerohanian ini sebenarnya bertujuan membawa dampak kepada kehidupan pelayan itu sendiri. sama seperti yang dikatakan oleh Alan E. Nelson bahwa: Mengembangkan dimensi rohani dalam kehidupan anda yang kemudian berdampak pada setiap bidang kehidupan seperti sikap, hubungan, citra diri, karakter, pengambilan keputusan, pekerjaan, tujuan, keluarga, kesenangan, kesehatan, seks, dan keuangan. ${ }^{43}$ Dengan hal itu pelayan Tuhan Akan dapat membawa pengaruh yang baik kepada jemaat yang dilayani, karena memang kerohanian dari pelayan itu sendiri sudah beres dan tidak perlu diragukan lagi.

\section{PENUTUP}

Berdasarkan paparan di atas, penulis memandang bahwa karakteristik seorang pelayan Tuhan yang baik haruslah dilihat dari tiga aspek yaitu : karakteristik seorang pelayan Tuhan dari aspek integritas, karakteristik seorang pelayan Tuhan dari aspek hubungan sosial dan karakteristik seorang pelayan Tuhan dari aspek kerohanian, ketiga aspek ini tidak dapat dipisahkan untuk melihat karakteristik seorang pelayan Tuhan yang baik yang harus dimiliki setiap orang yeng melayani Tuhan.

\footnotetext{
42 Tulus Tu'u, Pemimpin Kristiani Yang Berhasil 2 (Bandung : Bina Media Informasi, 2010), 47

${ }^{43}$ Alan E. Nelson, Spritual Intelligence (Yogyakarta : ANDI, 2011), 11
} 
Karakteristik seorang pelayan Tuhan dari aspek integritas, ini memberikan penjelasan bahwa setiap pelayan Tuhan haruslah memiliki integritas yang baik sebagai seorang pelayan Tuhan, dan ini dapat dilihat dari beberapa segi, yaitu, setiap pelayan Tuhan tidak boleh bercacat dari segi etis, harus memiliki satu istri, dapat menahan diri, bijaksana dan sopan, inilah yang harus ditunjukkan oleh setiap pelayan Tuhan. Karakteristik seorang pelayan Tuhan dari aspek hubungan sosial, ini memberikan penjelasan bahwa setiap pelayan Tuhan haruslah memiliki hubungan yang harmonis dalam hubungan sosial mereka, bukan sebaliknya pelayan Tuhan menjadi orang yang melakukan keribuatan. sehingga dari hal ini untuk melihat karakteristik seorang pelayan Tuhan yang baik dari segi hubungan sosial, setiap pelayan Tuhan haruslah seorang pelayan Tuhan yang suka memberikan Tumpangan, cakap mengajar orang, bukan peminum, bukan pemarah, bukan hamba uang, sebagai kepala keluarga yang baik, sebagai kepala keluarga yang disegani, sebagai kepala keluarga yang dihormati, dan memiliki nama baik diluar jemaat, hal inilah yang harus terus diperlihatkan serta dimiliki oleh setiap pelayan Tuhan.

Karakteristik seorang pelayan Tuhan dari aspek rohani ialah menjelaskan bagaimana seorang pelayan Tuhan haruslah memiliki kerohanian yang baik sebagai seorang pelayan Tuhan, karena memang setiap pelayan Tuhan harulah memiliki kerohanian yang baik supaya jemaat yang dilayani memiliki pertumbuhan kerohanian yang baik, justru sebaliknya jika kerohanian seorang pelayan Tuhan tidak baik maka kerohanian jemaat yang dilayani juga tidak akan mengalami pertumbuhan secara benar, sehingga dari hal itu sebagai seorang pelayan Tuhan janganlah memiliki kesombongan rohani dan mereka harus dipastikan sudah benar-benar menerima Kristus sebagai Juruselamat dalam jidup mereka, sehingga dengan hal itu mereka akan dapat melayani Tuhan dengan baik, karena memang kerohanian mereka sudah baik sebagai seorang pelayan Tuhan. 


\section{DAFTAR PUSTAKA}

.... (2007). Alkitab Terjemahan Baru, Jakarta: LAI.

Balz, Horst. dan Gerhard Schneider, Exegetical Dictionary Of The New Testament Volume 3, Germany : Kohlhammer.

Bible Works 7, CD-ROM.

Damazio, Frank. (2004). Memimpin Dengan Roh, Yogyakarta : ANDI.

Drewes, B. F. (2010). Kunci Bahasa Yunani Perjanjian Baru Surat Roma Hingga Wahyu, Jakarta : BPK Gunung Mulia.

Leigh, Ronald W. (2011). Melayani Dengan Efektif, Jakarta : BPK Gunung Mulia.

MacGrath, Alister E. (....). The NIV Thematic Study Bible.

Moulton, Harold K. (1978). The Analytical Greek Lexicon Revised, Grand Rapids: The Zondervan Corporation.

Nazir, Moh. (2014). Metode Penelitian, Bogor : Ghalia Indonesia.

Nelson, Alan E. (2011). Spritual Intelligence, Yogyakarta : ANDI.

Newman, Barclay M. (2014). Kamus Yunani-Indonesia Perjanjian Baru, Jakarta : Gunung Mulia.

Prayitno, Siswo, dan Hadi Podo. (2007). Kamus Besar Bahasa Indonesia, Jakarta : Pustaka Phoenix.

Sabdono, Erastus. (2017). Pelayanan Yang Sesungguhnya, Jakarta : Rehobot Literature.

Sopater, Sularso., dan Bambang Subandrijo. (1998). Kepemimpinan dan Pembinaan Warga Gereja, Jakarta : Pustaka Sinar Harapan.

Sribbs, A. M. (1996). Tafsiran Alkitab Masa Kini-Jilid 3, Jakarta : YKBK.

Sugiyono. (2015). Metode Penelitian Manajemen, Yogyakarta : ALFABETA.

Surjantoro, Bagus. (2001). Membangun Keluarga Untuk KemuliaanNya, Jakarta : Obor Mitra Indonesia.

Sutanto, Hasan. (2010). Perjanjian Baru Inteliniear Yunani-Indonesia jilid I dan Konkordansi PB (PBIK) Volume II, Jakarta: LAI.

Sutanto, Hasan. (2010). Perjanjian Baru Interlinear Yunani-Indonesia dan Konkordansi Perjanjian Baru (PBIK) Jilid I, Jakarta: LAI.

Trull, Joe E., dan James E. Carter. (2012). Etika Pelayanan Gereja, Jakarta : BPK Gunung Mulia. 
Tu'u, Tulus. (2010). Pemimpin Kristiani Yang Berhasil 2, Bandung : Bina Media Informasi.

Welt, Don De. (1961). Paul's Letters To Timothy And Titus, Yerusalem : College Press.

Zodhiates, Spiros. (1993). The Complete Word Study Dictionary New Testament, Amerika: AMG International. 